\title{
PENGELOLAAN TENAGA PENDIDIK (GURU) DI RURAL AREA
}

\author{
Nasir $^{1}$, Mujiati ${ }^{2}$, Hasmira Said ${ }^{3}$, Wresni Pujiyati ${ }^{4}$, Adam $^{5}$ \\ Universitas Muhammadiyah Kendari ${ }^{1,2,3,5}$ \\ Universitas Wiralodra 4 \\ dhion_zir@yahoo.com
}

\begin{abstract}
ABSTRAK
Penelitian ini ditujukan untuk menganalisis pengelolaan tenaga pendidik, khususnya pengadaan guru dan retensinya di rural area. Manfaat dari penelitian sebagai pedoman yang digunakan untuk meningkatkan dan memberikan daya tarik tersendiri pada para pendidik untuk mengabdikan dirinya dan mengajar di daerah terpencil. Sebagai objek penelitian meliputi: sistem pemetaan tenaga pendidik, lingkungan dan masyarakat (unsur guru, kepala sekolah, pemerintah dan masyarakat). Penelitian ini merupakan penelitian kualitatif yang dilakukan di Kecamatan Laonti. Data penelitian diperoleh dari wawancara, observasi dan dokumen terkait penelitian. Peneliti menerapkan prosedur model evaluasi CIPP melalui tahapan memahami, mensintesis, dan membandingkan teori yang ada. Kesimpulan penelitian ini adalah: pengadaan tenaga pendidik di rural area seharusnya dimulai dengan tahapan perekrutan, seleksi, penempatan, pemberian, kompensasi, penghargaan, pendidikan, latihan dan pemberhentian yang perlu diawasi secara berkesinambungan. Meskipun demikian, masih ditemukan aktifitasaktifitas unprofessional management khusunya pemanfaatan guru yang tidak sebidang dan beban kerja yang berlebihan sebagai konsekunsi dari kurangnya guru; 2) Retensi tenaga pendidik (guru) di rural area dapat dipenuhi dengan memberikan tunjangan khusus lebih bagi guru. Selain itu, pengadaan guru, bisa memprioritaskan calon guru yang berasal dari daerah tersebut.
\end{abstract}

Katakunci: Manajemen Tenaga Pendidik, Penyeteraan Pendidikan, Retensi Guru, Rural Area

\section{ABSTRACT}

This study is aimed at analyzing the management of teaching staff, specifically the provision of teachers and their retention in rural areas. The benefits of research as a guide are used to improve and provide a special attraction for educators to devote themselves and teach in remote areas. As objects of research include: the mapping system of educators, the environment and the community (elements of teachers, principals, government and community). This research is a qualitative study conducted in Laonti District. Research data obtained from interviews, observations and documents related to research. The researcher applies the CIPP evaluation model procedure through the stages of understanding, synthesizing, and comparing existing theories. The conclusion of this study is: the provision of teaching staff in rural areas should begin with the stages of recruitment, selection, placement, giving, compensation, rewards, education, training and termination that need to be monitored on an ongoing basis. However, unprofessional management activities are still found, especially the use of uneven teachers and excessive workload as a consequence of the lack of teachers; 2) The retention of educators (teachers) in rural areas can be fulfilled by providing more special allowances for teachers. In addition, the procurement of teachers, can prioritize prospective teachers who come from the area.

Keywords: Management of Educators, Education Equality, Teacher Retention, and Rural Areas

\section{PENDAHULUAN}

Rural area dapat diartikan dari berbagai perspektif. Kebalikan dari kawasan urban, rural area adalah sebuah aglomerasi permukiman di area perdesaan (Dasgupta et al., 
2015). Di Indonesia, istilah rural area adalah kawasan rural adalah wilayah yang mempunyai kegiatan utama pertanian, termasuk pengelolaan sumber daya alam dengan susunan fungsi kawasan sebagai tempat permukiman perdesaan, pelayanan jasa, pemerintahan, pelayanan sosial, dan kegiatan ekonomi (Mekar, Safitri, \& Sugito, 2014). Sementara itu, Dijkstra \& Poelman (2014) menyebutkan kawasan rural bahwa pembagian wilayah administratif di bawah kecamatan, yang dipimpin oleh Kepala Desa.

Sebagai kawasan terpencil, Kecamatan Laonti berada di Kabupaten Konawe Selatan Provinsi Sulawesi Tenggara. Dilihat dari wilayahnya Kecamatan Laonti berbatasan dengan Wawonii Kepulauan sebelah timur, Kecamatan Kolono sebelah selatan, Kecamatan Moramo sebelah barat dan Laut Banda pada sebelah utaranya. Kecamatan Laonti adalah salah satu kecamatan yang dapat dikategorikan sebagai Rural Area yang berada di Kabupaten Konawe Selatan. Meskipun Kecamatan Laonti sudah berdiri lama, namun bila dibandingkan dengan Kecamatan lain yang berada di Kabupaten Konawe Selatan, Kecamatan Laonti sangatlah tertinggal. Salah satu ketertinggalan Kecamatan Laonti disebabkan karena belum adanya akses darat yang menghubungkan Kecamatan Laonti dengan Kecamatan lain. Seperti, Kecamatan Moramo dan Kecamatan
Kolono yang terhubung dengan kecamatan lainnya dan memiliki akses darat menuju Kota Kendari.

Dalam banyak penelitian, penyelenggaraan pendidikan di kawasan rural, pengelolaan guru di daerah masih sangat mengkhwatirkan karena kekurangan guru berkualitas (Adlim, Gusti, \& Zulfadli, 2016). Pelaksanaan pendidikan di rural area jauh dari efisien, dimana pemanfaatan tenaga pendidik yang ada belum mampu menghasilkan lulusan yang diharapkan (Rahmawati, Nurzaima, \& Nasir, 2019). Banyaknya pengangguran di rural area dikarenakan oleh kualitas pendidikan yang telah mereka peroleh (Chakanika, Sichula, Sumbwa, \& Nduna, 2012). Pendidikan yang mereka peroleh tidak menjamin mereka untuk mendapatkan pekerjaan sesuai dengan jenjang pendidikan yang mereka jalani (Peterson, Mclntyre, \& Heppner, 2019).

Sebenarnya, Undang-Undang Republik Indonesia Nomor 14 tahun 2005 tentang guru dan dosen Pasal 1 ayat 14 telah menegaskan bahwa pengadaan guru pada pendidikan anak usia dini jalur pendidikan formal, pendidikan dasar, dan/atau pendidikan menengah, serta untuk menyelenggarakan dan mengembangkan ilmu kependidikan dan non kependidikan adalah tanggungjawab pemerintah. Meskipun demikian, masih banyak 
sekolah-sekolah yang mengeluhkan tentang kurangnya tenaga pendidik, baik untuk sekolah tingkat SD, SMP hingga SMA. Akibat kurangnya tenaga pendidik di daerah Kecamatan Laonti berdampak pada pembelajaran di sekolah-sekolah. Sehingga sering ditemukan guru yang mengajar tidak sesuai dengan bidangnya dan guru yang mengajar lebih dari satu mata pelajaran. Belum lagi di sekolah-sekolah tersebut lebih dominan guru honorer di bandingkan guru PNS. Oleh karena itu, penulis fokus berkaitan dengan kajian pengelolaan tenaga pendidik di Rural Area.

\section{METODE PENELITIAN}

Penelitian ini menggunakan pendekatan kualitatif. Peneliti mencatat dan melakukan pencocokan data, membuat yang samar menjadi nyata, menghubungkan akibat dengan sebab yang memverifikasi dugaan, mengkoreksi dan modifikasi temuantemuan penelitian sebelumnya. Data digali dari para informan (pemerintah setempat, kepala sekolah, guru, dan masyarakat). Observasi dan telah dokumen yang relevan dilakukan untuk memperkaya data. Penggunakan teknil pengumpulan data tersebut untuk menelusuri: Bagaimana pengadaan tenaga pendidik di Kecamatan Laonti? Dan Bagaimana retensi tenaga pendidik di Kecamatan Laonti?
Adapun analisis data dilakukan sebagaimana prosedur metode penelitian evaluasi (membandingkan dengan tujuan yg telah ditetapkan, dan bagaimana cara pencapaiannya). Peneliti menerapkan model evaluasi CIPP untuk mengevaluasi kesesuaian aplikasi teori manajemen SDM dan fakta lapangan. Tahapan analisa data melalui tahapan-tahapan: memahami, mensintesis, dan membandingkan teori yang ada (David J. Ketchen \& Bergh, 2007).

\section{HASIL PENELITIAN DAN PEMBAHASAN}

\section{Hasil Penelitian}

Laonti adalah sebuah

kecamatan di Kabupaten Konawe Selatan, Sulawesi Tenggara, Indonesia. Untuk mencapai kecamatan Laonti harus menggunakan transportasi laut. Berdasarkan posisi geografisnya, Kecamatan Laonti memiliki batasbatas wilayah yaitu: Kecamatan Kolono, Kecamatan Kolono Timur, Kacamatan Moramo dan Kecamatan Moramo Utara. Kecamatan Laonti terdiri dari 20 desa, 19 Desa Definitif dan 1 desa Persiapan.

Profil pendidikan Kecamatan Laonti pada tahun ajaran 2017/2018 tercatat sebanyak 19 unit SD dengan 129 guru dan 1.623 murid. Pada tingkat SLTP tercatat 6 unit sekolah, dengan 47 guru dan 620 murid. Sedangkan tingkat SLTA tercatat 2 unit sekolah, dengan 23 guru dan 280 
murid. Berikut ini adalah tabel yang menunjukkan jumlah sekolah di Kecamatan Laonti.

Tabel 1. Jumlah Sekolah di Kecamatan Laonti

\begin{tabular}{|c|c|c|c|}
\hline \multirow{2}{*}{ No } & \multirow{2}{*}{ Nama Sekolah } & \multicolumn{2}{|c|}{ Jumlah Tenaga Pendidikan } \\
\hline & & Guru honor & Pegawai \\
\hline 1. & SD Negeri 1 Laonti & 6 & 9 \\
\hline 2. & SD Negeri 10 Laonti & 6 & 6 \\
\hline 3. & SD Negeri 12 Laonti & 6 & 7 \\
\hline 4. & SD Negeri 13 Laonti & 6 & 6 \\
\hline 5. & SD Negeri 14 Laonti & 6 & 6 \\
\hline 6. & SD Negeri 15 Laonti & 6 & 5 \\
\hline 7. & SD Negeri 2 Laonti & 6 & 7 \\
\hline 8. & SD Negeri 3 Laonti & 6 & 7 \\
\hline 9. & SD Negeri 4 Laonti & 6 & 7 \\
\hline 10. & SD Negeri 5 Laonti & 6 & 7 \\
\hline 11. & SD Negeri 6 Laonti & 6 & 8 \\
\hline 12. & SD Negeri 7 Laonti & 6 & 7 \\
\hline 13. & SD Negeri 8 Laonti & 6 & 6 \\
\hline 14. & SD Negeri 9 Laonti & 6 & 5 \\
\hline 15. & SD Negeri Satap 16 Konawe Selatan & 6 & 5 \\
\hline 16. & SD Negeri Satap 1 Konawe Selatan & 6 & 4 \\
\hline 17. & SD Negeri Satap 12 Konawe Selatan & 6 & 9 \\
\hline 18. & SD Negeri Satap 6 Konawe Selatan & 6 & 8 \\
\hline 19. & SDN 11 Laonti & 6 & 6 \\
\hline 20. & SD-SMPN Satap 12 Konawe Selatan & 3 & 6 \\
\hline 21. & SMP Negeri 14 Konawe Selatan & 8 & 13 \\
\hline 22. & SMP Negeri 28 Konawe Selatan & 6 & 8 \\
\hline 23. & SMP Negeri Satap 1 Konawe Selatan & 3 & 9 \\
\hline 24. & SMP Negeri Satap 6 Konawe Selatan & 3 & 7 \\
\hline 25. & SMPN Satap 16 Konawe Selatan & 3 & 5 \\
\hline 26. & SMAN 21 Konawe Selatan & 3 & 7 \\
\hline 27. & SMAN 9 Konawe Selatan & 7 & 12 \\
\hline & Jumlah & 150 & 192 \\
\hline
\end{tabular}

Sumber: Kantor Camat Kecamatan Laonti, 2018

Rasio guru SD per sekolah sebesar 7 (sekitar 7 guru persekolah) dan rasio murid per guru 13 (ratarata satu guru untuk 13 murid). Rasio murid per sekolah 85 (rata-rata 85 murid per sekolah). Pada tingkat pendidikan SMP, rasio guru per sekolah sebesar 8 , rasio murid per guru sebesar 13 dan rasio murid per sekolah 103. Sedangkan di SMA, rasio guru per sekolah sebesar 12 , rasio murid per guru sebesar 12 dan rasio murid per sekolah 140. Bagamana rasio sekolah, guru dan siswa di Kecamatan Laonti sebagaimana terlihat pada gambar 1 berikut. 


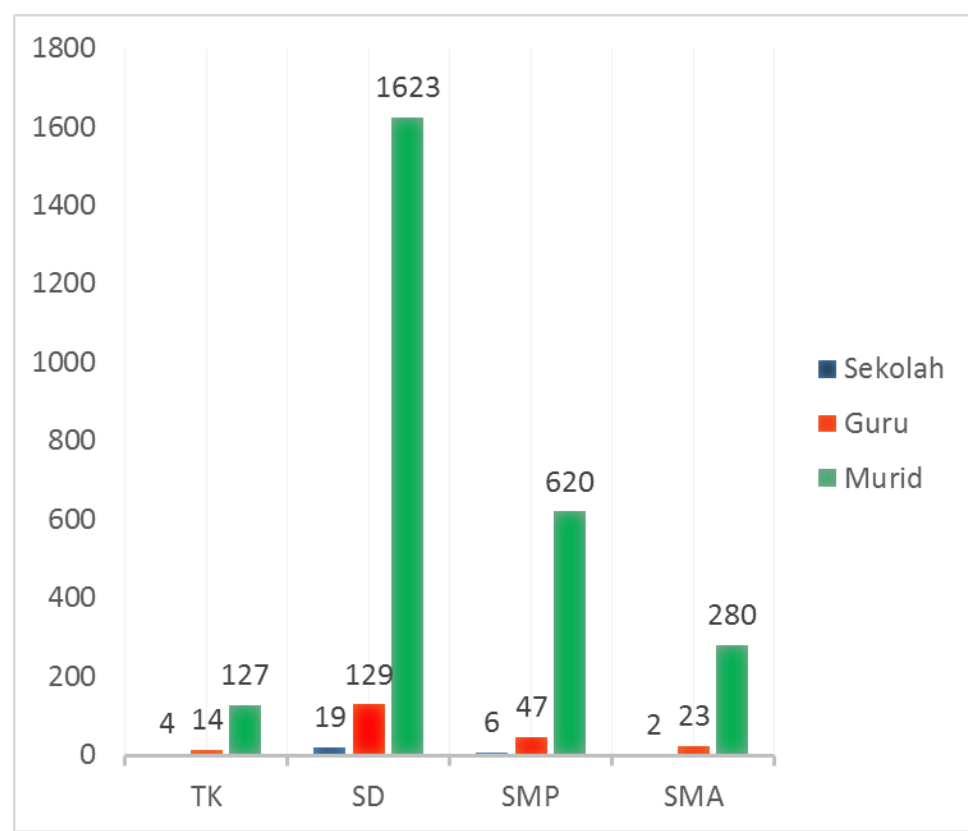

Gambar 1. Rasio sekolah, Guru dan Siswa di Sekolah-sekolah Kecamatan Laonti

Gambar di atas menunjukkan bahwa ada ketimpangan yang terjadi ada rasio guru dan siswa. Sebagaimana fokus penelitian ini, peneliti menilai bahwa terdapat mismanajen tenaga pendidikan di kecamatan Laonti. Oleh karena itu, pembahasan selanjutnya menggambarkan tentang pengadaan dan retensi guru di Laonti sebagai daerah rural area.

\section{Pengadaan Tenaga Pendidik di Kecamatan Laonti sebagai Daerah Kategori Rural Area}

1. Rekrutmen Tenaga Pengajar atau Guru

Karakteristik tenaga pengajar atau guru ditinjau dari statusnya terdiri dari dua, yakni guru PNS dan guru honorer. Guru PNS (Pegawai Negeri Sipil) adalah guru yang diangkat melalui rekrutmen CPNS, selanjutnya kehidupannya dijamin oleh negara, tempat tinggal, pakaian dan kendaraan semuanya dijamin oleh negara melalui bayaran yang diterimanya tiap bulan. Sedangkan guru honor adalah guru bukan PNS yang direkrut dan diberikan insentif oleh sekolah. Meskipun demikian penggunaan guru honor tidak lagi diperkenankan digunakan di sekolahsekolah.

Berdasarkan keterangan Kepala UPTD Pendidikan Kecamatan Laonti mengatakan bahwa "Pemerintah telah berencana untuk menyelesaikannya guru honorer bersertifikasi dan bisa menjadi PNS, sebaliknya sebaiknya sekolah lebih memberdayakan, pensiunan PNS untuk diminta mengabdi kembali 1 hingga 2 tahun, sambil menunggu CPNS baru". Dengan instruksi tersebut, maka status guru nanti 
hanyalah guru berstatus Pegawai Negeri Sipil (PNS) atau Pegawai Pemerintah dengan Perjanjian Kerja (PPPK). Selama ini sekolah mengangkat guru honorer untuk menutupi kekurangan guru PNS yang belum terdistribusi dengan baik.

Mengelola tenaga pendidik dan kependidikan merupakan kegiatan yang pasti dan harus dilakukan. Mulai dari tenaga pendidik/kependidikan dengan cara mengorganisasikan dan bertujuan dengan perekrutan, seleksi, penempatan, pemberian, kompensasi, penghargaan, pendidikan, latihan dan pemberhentian yang dijalankan secara terawasi. Tes CPPK diharapkan dapat menyelesaikan masalah pengangkatan guru honorer menjadi pegawai pemerintah dengan perjanjian kerja (P3K). Calon guru dan tenaga kependidikan yang akan diangkat menjadi guru atau tenaga kependidikan, dengan mempertimbangkan kelengkapan dokumen, pengetahuan calon guru atau tenaga kependidikan, hasil test psikologi dan wawancara. Biasanya dalam proses pengangkatan guru atau tenaga kependidikan akan menandatangani surat pernyataan bermaterai dan terkadang menandatangani surat kontrak. Untuk PNS dalam pengangkatan juga melalui tahap sumpah. Bagaimana prosedur seleksinya, kepala UPTD Pendidikan Kecamatan Laonti memberi ilustrasi sebagaimana petikan wawancara di bawah ini:
“Proses seleksi administrasi adalah tahap awal seleksi yang harus dipenuhi oleh pelamar. Dalam proses seleksi administrasi, pelamar harus mengisi formulir yang telah disediakan oleh instansi terkait, melengkapi lampiran-lampiran yang telah ditentukan oleh instansi terkait, dan memenuhi persyaratan finansial (membayar) jika ditentukan. Dan jika persyaratan dalam proses seleksi administrasi tidak dipenuhi maka bisa dipastikan kemungkinan besar pelamar tidak dapat melanjutkan tahap seleksi atau tidak lolos"

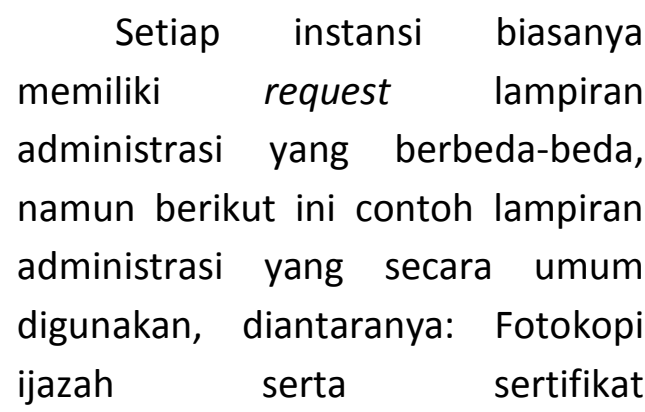
pelatihan/kursus yang telah dimiliki, daftar riwayat hidup, surat keterangan berkelakuan baik dari kepolisian, surat keterangan sehat dari dokter, kartu tanda bukti mencatatkan diri dari departemmen/dinas tenaga pendidik dan kependidikan setempat, pas foto sesuai dengan permintaan, fotokopi kartu tanda penduduk, dan surat keterangan pengalaman kerja.

Pada tahap tes psikologi, calon guru akan mengikuti dan menjalankan test yang didesain khusus untuk mengetahui kepribadian, tingkat intelligensi, 
bakat-minat dan semua yang berhubungan dengan psikis pelamar. Sedangkan pada tahap wawancara pelamar akan diwawancarai oleh perwakilan dari instansi, dimana pihak pelamar akan ditanyai seputar pengalaman, tujuan kerja, dan halhal lainnya.

\section{Penempatan Tenaga Pengajar atau Guru}

Secara umum, manajemen sumber daya manusia merupakan upaya pengaturan seseorang untuk menempati posisi dalam suatu jabatan. Penempatan inilah yang nantinya menentukan hasil output dan mempengaruhi susunan ketenagaan dalam struktur organisasi pendidikan nasional. Prinsip "the right man on the right place" adalah prinsip yang harus dipenuhi dalam penempatan ini.

Penempatan guru di daerah juga dipengaruhi oleh adanya otonomi daerah. Sehingga, pemenuhan guru akan mengutamakan prioritas dari kebutuhan wilayahnya. Cara ini tentu akan menimbulkan masalah pada sebagian daerah yang mengalami kekurangan guru tetapi tidak memiliki SDM yang sesuai. Dari wawancara peneliti kepada informan diketahui jika seringkali kepala sekolah atau masyarakat mengeluh tentang sebaran tenaga pendidik yang tidak merata. Secara nasional sebaran guru menjadi salah satu masalah. la mengatakan distribusi guru diharapkan merata pada semua unit sekolah se-Sultra termasuk di daerah, sehingga proses belajar mengajar berjalan efektif dan mencapai sasaran.

Umumnya guru laki laki maupun perempuan memilih atau berdalih segala cara untuk pindah tugas dari sekolah luar kota ke sekolah sekitar perkotaan, katanya! Padahal mengabdi di sekolah luar kota atau daerah terpencil akan banyak memperoleh hikmah. Salah satunya, adalah memperoleh tambahan pendapatan luar gaji pokok dan kalau kreatif akan memiliki aset kebun atau lahan pertanian dengan memanfaatkan waktu luang.

Penempatan guru tentunya harus mendapat perhatian pusat dan daerah. Kerja sama dalam penempatan guru juga bisa dilakukan antar daerah melalui lembaga dan institusi yang jelas. Lembaga dan institusi ini haruslah institusi yang dapat mendekatkan antara sekolah yang membutuhkan guru, perguruan tinggi penghasil lulusan guru dan lulusan calon guru itu sendiri.

Distribusi guru di Indonesia tidak merata, meski jumlahnya sudah cukup memadai. Sebagian besar masih terkonsentrasi di kota-kota besar. Penempatan guru di Indonesia mengalami masalah terutama di wilayah $3 \mathrm{~T}$, yaitu wilayah tertinggal, terpencil dan terluar. Di wilayah ini, kualitas pendidikan masih sangat jauh dari pendidikan yang ada di 
wilayah perkotaan. Bahkan, pengajar yang ada wilayah $3 \mathrm{~T}$ ini sangatlah minim, kualitas akademisnya juga tidak memenuhi standar yang seharusnya.

Beberapa faktor penyebab menumpuknya guru di kota-kota karena jumlah siswa dan gedung memang masih terpusat di kota. Faktor lain, banyak pula guru yang enggan berada di daerah terpencil dengan pertimbangan gaji yang kurang memadai. Guru juga mengeluh karena buruknya kondisi jalur transportasi, jarak tempuh yang cukup menguras waktu dan tenaga sehingga mereka tidak merasa nyaman. Tentu, kalau jalur transportasi ditangani serius oleh pemerintah, dampak positifnya bukan hanya dirasakan oleh guru, tapi mampu mendongkrak perekonomian masyarakat di sana. Kedua, sama dimaklumi bahwa selama ini kami yang ditempatkan di wilayah terpencil rata-rata cepat merasa bosan. Faktor utamanya adalah karena mereka terlalu lama bertugas di sana, dan berpisah dari keluarganya.

Berdasakan fakta pendidikan di rural area, kiranya perlu dipikirkan alternatif lain untuk mengatasi persoalan pendidikan di wilayah terpencil. Intinya pemerintah tidak hanya menuntut bahwa semua guru harus rela ditugaskan di mana pun. Itu memang benar, tapi sejauh mana selama ini pemerintah menjamin tingkat kenyamanan guru dalam menjalankan tugasnya di daerah terpencil? Perlu dirumuskan langkah baru yang intinya tidak mengurangi semangat guru untuk mau mengabdi di daerah terpencil.

Peningkatan pemerataan penempatan guru dan tenaga kependidikan ini telah tertera di dalam surat keputusan 20 juli 2016 yang di tandatangani oleh menteri pendidikan dan kebudayaan saat itu, Anies Baswedan. Dalam surat tersebut Anies, menghimbau kepada kepala daerah yang mencakup gubernur, bupati/walikota di seluruh Indonesia untuk menempatkan masyarakat yang berprofesi sebagai guru dan tenaga kependidikan secara merata tanpa membeda-bedakan.

\section{Retensi Tenaga Pendidik di Kecamatan Laonti \\ Retensi pekerja adalah suatu} keharusan yang perlu dilakukan oleh perusahaan guna mempertahankan Sumber Daya Manusia (SDM) terbaik yang dimilikinya. Retensi pekerja dapat dimaknai sebagai upaya mempertahankan tenaga kerja agar tetap loyal dan setiap terhadap perusahaanya. Melakukan retensi karyawan juga bisa dilakukan untuk bisa mendapatkan solusi agar bisa meminimalisir turnover karyawannya serta meningkatkan rasa nyaman karyawan dalam sebuah perusahaan. Dalam lingkup pendidikan, retensi bisa diartikan sebagai upaya untuk mengatraksi guru agar tetap 
semangat dan sepenuh hati bertugas sebagai tenaga pengajar.

Demikian pula retensi guru di daerah/pelosok adalah sebuah keharusan, agar mereka tetap betah mengabdikan diri di daerah. Hidup guru di sekolah terpencil sering kali tidak layak dan kerap kali tidak difasilitasi akomodasi yang layak. Beberapa tanggapan tentang faktorfaktor yang membuat guru di Laonti kurang betah sebagaimana petikan wawancara beberapa informan guru di bawah ini:

"Guru di tempat saya sering kali harus menempuh puluhan kilometer serta menyeberang sungai hanya untuk mengajar. Sering kali mereka tidak mendapatkan tempat tinggal yang layak. Tidak adanya fasilitas yang memadai dan insentif yang jelas jadi alasan mengapa kami enggan ditugaskan di daerah terpencil"

\section{Guru 1}

"Selain itu, alasan kenyamanan di sekolah yang telah didiami, serta jauh dari keluarga juga sering dialami para guru. Banyak pula dari guru yang sebentar lagi akan pensiun sehingga merasa tidak perlu dipindah-pindahkan lagi"

\section{Guru 2}

"Di sisi lain, guru lokal merasa terancam dengan kedatangan guru pendatang karena hadirnya anggapan guru pendatang hanya memanfaatkan sekolah terpencil sebagai loncatan karier semata. Mereka berpikir sebaiknya guru lokal saja yang menjadi pengajar di daerahnya. Guru PNS jarang bertahan lama dan dianggap hanya menjadikan sekolah mereka sebagai batu loncatan"

\section{Guru 2}

"Ketidakramahan pengajar lokal menjadi salah satu alasan para guru pendatang tidak betah mengajar di sekolah terpencil. Tidak terfasilitasinya guru di daerah terpencil oleh pemerintah membuat para guru enggan dipindahkan ke sekolah di daerah terpencil"

Tanpa adanya kemauan untuk bertahan dengan kondisi sulit tersebut, mengajar bisa jadi hal yang berat dan memicu stress pada guru hal ini ditunjukkan dengan tingginya tingkat burnout dan hilangnya antusias dalam mengajar para guru. Mendalami fenomena tersebut, peneliti telah menanyakan kepada beberapa informan di kecamatan Laonti solusi-solusi yang mungkin bisa dilakukan pihak berwenang untuk membuat betah para guru di daerah. Hasil wawancara peneliti terangkum pada petikan-petikan di bawah ini:

Kepala UPTD Pendidikan

"Hal yang patut dipikirkan serius dan direalisasikan oleh pemerintah adalah perbaikan dan peningkatan kualitas jalur transportasi. Secara umum 
akses jalan ke wilayah terpencil sangat memprihatinkan. Masih banyak jalan yang belum diaspal, bahkan sebagiannya hanya mampu dilewati kendaraan roda dua. Mengapa jalur tranportasi penting ditangani serius? Karena inilah alasan utama sebagian besar guru yang bertugas ke wilayah terpencil. Mereka mengeluh karena buruknya kondisi jalur transportasi, jarak tempuh yang cukup menguras waktu dan tenaga sehingga mereka tidak merasa nyaman. Tentu, kalau jalur transportasi ditangani serius oleh pemerintah, dampak positifnya bukan hanya dirasakan oleh guru, tapi mampu mendongkrak perekonomian masyarakat"

Kepala Sekolah

$\begin{array}{lr}\text { "Sama dimaklumi } & \text { bahwa } \\ \text { selama ini guru } & \begin{array}{r}\text { yang } \\ \text { ditempatkan di }\end{array} \\ \text { wilayah } \\ \text { terpencil rata-rata } & \text { cepat } \\ \text { merasa bosan. } & \text { Faktor } \\ \text { utamanya adalah karena } & \text { ka } \\ \text { mereka terlalu lama bertugas } \\ \text { di sana, dan berpisah dari } \\ \text { keluarganya. Boleh jadi kalau } \\ \text { penugasan dibatasi hanya satu } \\ \text { semester atau paling lama satu } \\ \text { tahun, misalnya, mereka } \\ \text { mungkin akan betah dalam } \\ \text { tugasnya. }\end{array}$

Kepala UPTD Pendidikan

"Untuk membangkitkan gairah pegabdian di daerah terpencil, pemerintah perlu memberikan tunjangan khusus lebih bagi guru. Tunjangan khusus lebih yang saya maksudkan adalah

\begin{abstract}
lebih dari perhitungan tunjangan satu kali lipat dari gaji pokok, tetapi juga mempertimbangkan kondisi wilayah tempat tugas guru. Guru dengan jarak lebih jauh diberikan tunjangan tambahan oleh pemerintah daerah"

\section{Kepala UPTD Pendidikan}

"Ketika ada penerimaan calon pegawai negeri sipil (CPNS) untuk formasi guru, jika memungkinkan khusus untuk guru daerah terpencil cari saja dan prioritaskan calon guru yang memang berasal dari daerah tersebut. Dari pada seleksi dengan sistem online yang berlaku secara Nasional saat ini, guru yang lulus misalnya dari provinsi dan kabupaten lain, maka dalam waktu dekat pasti akan mengajukan pindah tugas setelah mendapatkan SK seratus persen dengan berbagai upaya. Kalau guru yang bertugas di sana adalah putra setempat, kemungkinan untuk mengajukan pindah tugas sangat tipis"
\end{abstract}

Semua kondisi dan masalah ril yang ada di daerah terpencil menjadi masalah bersama yang menggugah rasa nasionalisme kita untuk mengatasinya. Dalam perpektif ini rasa nasionalisme yang kita bangun terbentuk melalui kesadaran universal dari seluruh komponen bangsa untuk bersama-sama memberi prioritas bagi percepatan pelayanan pendidikan dan peningkat 
mutu pendidikan di daerah terpencil tersebut

\section{Pembahasan Hasil Penelitian}

1. Penyediaan guru di Daerah Rural Area (Terpencil)

Mengelola tenaga pendidik dan kependidikan merupakan tugas yang mutlak dan harus dilakukan jika kita mengharapkan pendidikan yang bermutu (Everard, Morris, \& Wilson, 2004). Pengelolaan tersebut dimulai dari perekrutan, seleksi, penempatan, pemberian, kompensasi, penghargaan, pendidikan, latihan dan pemberhentian yang dijalankan secara terawasi (Cobanoglu, Sertel, \& Sarkaya, 2018). Di tingkat nasional, pengelolaan tenaga kependidikan merupakan langkah penting dalam mewujudkan sistem pendidikan nasional yang efektif dan efisien. Tenaga-tenaga handal dalam dunia pendidikan hanya bisa diperoleh apabila sistem pendidikan telah memiliki mekanisme yang ideal untuk melakukan perekrutan, seleksi, penempatan, pembinaan, evaluasi dan pemberhentian. Dengan kata lain sistem pendidikan nasional memerlukan strategi pengelolaan tenaga kependidikan yang searah dengan pencapaian tujuan pendidikan nasional.

Sebagaimana aspek-aspek kegiatan manajemen tenaga kependidikan atau kepegawaian (Butcher, 2007), antara lain: a) Recruitment atau penarikan mulai dari pengumuman penerimaan pegawai, pendaftaran, pengetesan, pengumuman diterimanya pegawai sampai dengan daftar ulang.

b) Placement atau penempatan, yaitu proses penanganan pegawai baru yang sudah melaksanakan pendaftaran ulang untuk diberi tahu pada bagian seksi mana mereka ditempatkan. Penugasan dilakukan sesuai dengan bidang keahlian dan kebutuhan lembaga. Didalam tahap ini sebenarnya penanganan bukan berarti sampai menempatkan dan memberi tugas saja, tetapi juga menggunakan pegawai tersebut sebaik-baiknya, merangsang kegairahan kerja dengan menciptakan kondisi atau suasana kerja yang baik. Di samping itu juga memberi kesejahteraan pegawai berupa gaji, insentif, memberi cuti izin, dan pertemuan-pertemuan yang bersifat kekeluargaan.

c) Development atau pengembangan, dimaksudkan untuk penigkatan mutu pegawai baik dilakukan dengan melalui pendidikan maupun kesempatan-kesempatan lain seperti penataran, diskusi 
ilmiah, lokakarya, membaca majalah dan surat kabar, menjadi anggota organisasi profesi dan lain sebagainya. Mengatur kenaikan pangkat dan kenaikan gaji, dapat dikategorikan sebagai pemberian kesejahteraan dan dapat dikategorikan sebagai pengembangan pegawai. Pegawai yang diberi penghargaan dengan atau pemberian kedudukan, akan mendorong pegawai tersebut untuk lebih meningkatkan tanggung jawabnya.

d) Pengawasan atau evaluasi, merupakan aspek terakhir dalam penanganan pegawai. Pada tahap ini dimaksudkan bahwa pada tahap-tahap tertentu pegawai diperiksa, apakah yang mereka lakukan sudah sesuai dengan tugas yang seharusnya atau belum. Selain evaluasi atau penilaian juga dilakukan untuk mengetahui tingkat kenaikan kemampuan personil setelah mereka memperoleh pembinaan dan pengembangan.

Kekurangan guru menjadi salah satu masalah dalam dunia pendidikan yang hingga kini belum terselesaikan. Berbagai cara sudah dilakukan pemerintah, seperti mengirimkan para sarjana ke daerahdaerah pelosok untuk menjadi tenaga pendidik. Meski demikian, mengirimkan guru ke berbagai daerah tidak bermakna segala masalah sudah selesai. Merujuk Chan \& Yuen (2015), mereka mengatakan sudah seharusnya pemerintah pusat bekerjasama dengan pemerintah daerah untuk memberdayakan para guru-guru lokal di daerah. Guru-guru lokal ini lebih memahami kondisi geografis di daerah pelosok. Oleh karena itu, akan lebih mudah bagi mereka berada di daerah-daerah seperti itu.

Pemberdayaan guru lokal di daerah pelosok akan lebih efektif jika dibandingkan hanya mengandalkan pengiriman guru dari kota karena guru dari kota belum tentu bertahan lama mengajar di daerah terpencil. Betahnya mungkin hanya satu atau dua tahun. Sedangkan bila mengangkat guru lokal, selain sudah terbiasa dengan kondisi geografis, mereka juga bisa mengajari anak didiknya dengan bahasa ibu atau bahasa keseharian peserta didik.

Sebenarnya, saat ini Indonesia tidak kekurangan guru. Namun distribusinya yang belum merata sehingga masih banyak sekolahsekolah yang kekurangan guru. Tentunya, distribusi guru masih menjadi isu yang selalu muncul dalam masalah pendidikan. Tidak hanya Indonesia, secara umum banyak negara mengalami masalah dengan besarnya jumlah guru berkualitas di bawah standar dan tidak layaknya pelatihan profesional 
bagi mereka. Data statistik UNESCO Institute memperkirakan, agar seluruh anak di dunia mendapatkan pendidikan dasar pada 2020, semua negara membutuhkan 25,9 juta guru (Egeberg, 2017).

2. Strategi Retensi Tenaga Pendidikan di Daerah Terpencil Pada jenjang pendidikan formal, secara umum perluasan akses dan peningkatan pemerataan pendidikan masih menjadi masalah utama, terutama bagi masyarakat miskin maupun masyarakat di daerah terpencil. Pemerataan pendidikan formal terdiri dari pemertaaan pendidikan di tingkat prasekolah, sekolah dasar, menengah, perguruan tinggi. Pendidikan prasekolah merupakan pendidikan pada anak usia dini, semisal: playgroup dan taman kanak-kanak. Pada daerah perkotaan pendidikan prasekolah secara formal sudah sering ditemukan, tetapi untuk daerah terpencil seperti di pedesaan, masih sangat jarang. Pendidikan sekolah dasar memang sudah cukup dirasakan pemerataannya di berbagai daerah, hal ini sejalan dengan program wajib belajar 9 tahun, tetapi mutu dari pendidikan tersebut masih sangat berbeda antara daerah perkotaan dengan pedesaan.

Sesuai dengan amanat Undangundang Dasar 45 pasal 31: (1) Setiap warga negara berhak mendapat pendidikan; (2) Setiap warga negara wajib mengikuti pendidikan dasar dan pemerintah wajib membiayainya; (3) Pemerintah mengusahakan dan menyelenggarakan satu sistem pendidikan nasional, yang meningkatkan keimanan dan ketakwaan serta akhlak mulia dalam rangka mencerdaskan kehidupan bangsa, yang diatur dengan UndangUndang; (4) Negara memprioritaskan anggaran pendidikan sekurang-kurangnya dua puluh persen dari anggaran pendapatan dan belanja negara serta dari anggaran pendapatan dan belanja daerah untuk memenuhi kebutuhan penyelenggaraan pendidikan nasional; dan poin (5) Pemerintah memajukan ilmu pengetahuan dan teknologi dengan menjunjung tinggi nilai-nilai agama dan persatuan bangsa untuk kemajuan peradaban serta kesejahteraan umat manusia.

Lesson study yang bisa dipetik dari Pasal 31 UUD 1945 tersebut adalah setiap warga negara berhak mendapatkan pendidikan tanpa kecuali. Tetapi, pada kenyataannya dengan kondisi negara Indonesia yang sangat luas dan terdiri dari ribuan pulau, mulai Sabang sampai Merauke, dihadapkan dengan berbagai permasalahan pelayanan pendidikan bagi masyarakat. Padahal pendidikan merupakan faktor utama dalam menentukan kemajuan sebuah bangsa. Dengan tingkat pendidikan yang tinggi, maka akan 
semakin baik sumber daya manusia yang ada, dan pada akhirnya akan semakin tinggi pula daya kreatifitas pemuda Indonesia dalam mengisi pembangunan sebuah bangsa. Namun di Indonesia, untuk mewujudkan pendidikan yang baik dan berkualitas sesuai dengan standar nasional saja masih sangat sulit.

Berbagai permasalahan seringkali menghambat peningkatkan mutu pendidikan nasional, khususnya di daerah tertinggal atau terpencil, yang pada akhirnya mewarnai perjalanan pendidikan di Indoensia. Di suatu daerah terpencil masih banyak dijumpai kondisi di mana anak-anak belum terlayani pendidikannya. Angka putus sekolah yang masih tinggi. Juga masalah kekurangan guru, walaupun pada sebagain daerah, khususnya daerah perkotaan persediaan guru berlebih. Sarana dan prasarana yang belum memadai. Itulah sederat fakta-fakta yang menghiasii wajah pendidikan kita di daerah terpencil.

Terkait dengan masalah pemenuhan tenaga pendidik, pemerintah kita (melalui dinas pendidikan) sebenarnya secara khusus telah berusaha melakukan pemenuhan melalui penempatan guru-guru Pegawai Negeri Sipil (PNS) baru yang ditempatkan di daerah tertinggal atau terpencil. Akan tetapi, fakta di lapangan menunjukkan bahwa banyak guru yang enggan mengajar di daerah terpencil dengan beragam alasan. Merujuk Mwaisumo (2016), salah satu faktor yang menyebabkan keengganan para guru untuk mengajar di daerah terpencil atau tertinggal adalah letak sekolah yang sulit dijangkau. Alasan berikutnya adalah minimnya fasilitas dan hiburan (Uysal \& Çağanağa, 2018). Di Indonesia, pada umumnya guru yang mengajar di daerah terpencil tidak betah dikarenakan fasilitas yang tidak memadai. Selain jauh dari pusat keramaian, fasilitas tempat tinggal guru juga tidak dipenuhi oleh pemerintah. Akibatnya banyak guru yang merasa tidak nyaman dan mengajukan pindah ke sekolah yang berada di perkotaan.

Dengan adanya berbagai permasalahan penyelenggaran pendidikan di daerah tertinggal atau terpencil, seharusnya masalah pelayanan pendidikan tidak hanya menjadi tanggung jawab pemerintah. Masyarakat luas, melalui berbagai organisasi kemasyarakatan, NGO, dan organisasi lainnya bisa ikut terlibat dalam membantu mengatasi berbagai kekurangan layanan pendidikan di daerah terpencil. Sebagaimana dikatakan seorang informan pada paparan temuan penelitian sekiranya bisa menjadi sebuah masukan bagi pemerintah sebagai pengambil kebijakan.

Membangkitkan semangat dan loyalitas guru di daerah terpencil, pemerintah perlu memberikan 
tunjangan khusus lebih bagi guru. Tunjangan khusus lebih yang dimaksudkan adalah lebih dari perhitungan tunjangan satu kali lipat dari gaji pokok. Selain itu, mempertimbangkan kondisi wilayah tempat tugas guru. Mengadakan calon guru, jika memungkinkan khusus untuk guru daerah terpencil bisa memprioritaskan calon guru yang berasal dari daerah tersebut.

\section{KESIMPULAN}

Penelitian ini menyimpulkan beberapa hal, yaitu: Masih ditemukan aktifitas-aktifitas unprofessional management khusunya pemanfaatan guru yang tidak sebidang dan beban kerja yang berlebihan sebagai konsekunsi dari kurangnya guru. Guru yang mengajar di rural area juga tidak betah dikarenakan fasilitas yang tidak memadai. Selain jauh dari pusat keramaian, fasilitas tempat tinggal guru juga tidak dipenuhi oleh pemerintah. Akibatnya banyak guru yang merasa tidak nyaman dan mengajukan pindah ke sekolah yang berada di perkotaan. Oleh karena itu, pengelolaan tenaga pendidik di rural area (terpencil) harus mengaplikasikan dengan benar konsep-konsep perekrutan guru, seleksi, penempatan, pemberian, kompensasi, penghargaan, pendidikan, latihan dan pemberhentian yang perlu diawasi secara berkesinambungan. Retensi tenaga pendidik (guru) juga harus dilakukan secara maksimal.

Peneliti juga merekomendasikan gagasan untuk perbaikan manajemen tenaga pendidik dan kependidikan. Rekomendasi tersebut akan efektif jika diaplikasikan di wilayah terpencil atau daerah rural area lainnya. Dengan adanya berbagai permasalahan penyelenggaran pendidikan di daerah tertinggal atau terpencil, seharusnya masalah pelayanan pendidikan tidak hanya menjadi tanggung jawab pemerintah akan tetapi masyarakat luas, dan organisasi kemasyarakatan bisa ikut terlibat dalam membantu mengatasi berbagai kekurangan layanan pendidikan di daerah terpencil. Membangkitkan semangat dan loyalitas guru di daerah terpencil, pemerintah perlu memberikan tunjangan khusus lebih bagi guru. Tunjangan khusus lebih yang dimaksudkan adalah lebih dari perhitungan tunjangan satu kali lipat dari gaji pokok. Selain itu, mempertimbangkan kondisi wilayah tempat tugas guru. Mengadakan calon guru, jika memungkinkan khusus untuk guru daerah terpencil bisa memprioritaskan calon guru yang berasal dari daerah tersebut.

\section{DAFTAR PUSTAKA}

Adlim, Gusti, H., \& Zulfadli. 2016. Permasalahan dan Solusi Pendidikan di Daerah Kepulauan (Studi kasus di SMA 
Negeri 1 Pulau Aceh, Kabupaten Aceh Besar). Jurnal Pencerahan, 10(1), 48-61. https://doi.org/https://doi.org /10.13170/jp.10.2.4910

Butcher, J. 2007. Human Resource Management: Managerial Efficacy in Recruiting and Retaining Teachers - National Implications William Allan Kritsonis, PhD PhD Program in Educational Leadership College of Education and Professional Studies.

Chakanika, W., Sichula, N., Sumbwa, P., \& Nduna, M. 2012. The challenges of rural education in Africa. South Africa Rural Educator, 2(Desember), 6-17.

Chan, T., \& Yuen, M. 2015. Inclusive Education in an International Schoold: A Case Study from Hongkong. International Journal of Special Education, 30(3), 86-97.

Cobanoglu, F., Sertel, G., \& Sarkaya, S. S. 2018. Human resource management practices in Turkish education system (Denizli case). European Journal of Educational Research, 7(4), 833-847. https://doi.org/10.12973/eujer.7.4.833

Dasgupta, P., Morton, J. F., Dodman, D., Karapinar, B., Meza, F., Rivera-Ferre, M., ... Broecker, H. 2015. Rural areas. In Climate Change 2014 Impacts, Adaptation and Vulnerability: Part A: Global and Sectoral Aspects (pp. 613-658). https://doi.org/10.1017/CBO9 781107415379.014
David J. Ketchen, J., \& Bergh, D. D. 2007. Research Methodology in Strategy and Management (4th ed.). Amsterdam: JAI Press.

Dijkstra, L., \& Poelman, H. 2014. Regional Working Paper 2014 A harmonised definition of cities and rural areas: the new degree of urbanisation. Retrieved from https://ec.europa.eu/regional _policy/sources/docgener/wor k/2014_01_new_urban.pdf

Egeberg, M. 2017. Merit-based recruitment boosts good governance : How do European Union agencies recruit their personnel ?

https://doi.org/10.1177/00208 52317691342

Everard, K. B., Morris, G., \& Wilson, I. 2004. Effective School Management (4th ed.). Great Britain: Paul Chapman Publishing.

Mekar, S. S., Safitri, D., \& Sugito. 2014. Klasifikasi Wilayah DesaPerdesaan dan Desa-Perkotaan Wilayah Kabupaten Semarang dengan Support Vector Machine (SVM). Jurnal Gaussian, 3(2010), 751-760.

Mwaisumo, W. N. 2016. The Recruitment of Support Staff in Tanzanian Secondary Schools. Journal of Education and Practice, 7(19), 86-89.

Peterson, S. S., McIntyre, L., \& Heppner, D. 2019. Northern Rural and Indigenous Teachers ' Experiences and Perceptions of Rural Teaching and Teacher Education Northern Rural and Indigenous Teachers 
Experiences and Perceptions of Rural Teaching and Teacher Education. Journal of Teacher Education and Educators, 7(3).

Rahmawati, M., Nurzaima, \& Nasir. 2019. Pengembangan Profesi Berkelanjutan Guru SMA Negeri Kota Kendari. Didaktis: Jurnal Pendidikan Dan IImu Pengetahuan, 19(2), 132-146. https://doi.org/http://dx.doi.o rg/10.30651/didaktis.v19i2.28 94

Undang-Undang Republik Indonesia. 2005. Undang-Undang Nomor 14 tahun 2005 tentang Guru dan Dosen.

Undang-undang Dasar 45 pasal 31 ayat 1 - 5 .

Uysal, M., \& Çağanağa, Ç. K. 2018. Teachers ' opinions of human resources management functions in private schools. Educational Research and Reviews, 13(12), 487-494. https://doi.org/10.5897/ERR20 17.3407 